\title{
A NOTE ON SOURCES
}

\section{Abbreviations}

AFS Archives Fédérales Suisses, Bern, E 4320, Arslan

ASMAE Archivio Storico del Ministero degli Affari Esteri, Rome

FO Foreign Office Records, Public Record Office, London

LNA La Nation Arabe

MAE Archives du Ministère des Affaires Etrangères, Paris

NA Microfilm Records of the German Foreign Office Received by the U.S. Department of State, National Archives, Washington, D.C.

$R R \quad$ Shakib Arslan, al-Sayyid Rashid Rida aw ikha' arba'in sanah

\section{Transliteration}

French and English scholars have adopted distinct systems of Arabic transliteration. This particularly affects a study which focuses on the life of an Eastern Arab active in French North Africa. Julien's l'Emir Chekib is Hourani's Amir Shakib. I have not tried to reconcile them. Names of well-known Maghribi figures are spelled according to the French method as adopted by John P. Halstead in Rebirth of a Nation. In other instances, diacritical marks have been reserved for 'ayn and for medial and terminal hamza. 
The titles of articles written in Arabic are cited in translation in the notes. The specialist who wishes to consult the article will be able to find it; the nonspecialist will have a sharper sense of the topic. Book titles are noted in transliteration. The entry in the bibliography includes a translated title.

The most public of men, Arslan has bequeathed to the biographer an abundance of sources. A prolific and often repetitive writer, his oeuvre included twenty books, two collections of poetry, and some two thousand articles. Although only one of the books is an autobiography (covering the years to I923), he was never averse to selfadvertisement, and large sections of his other works are devoted to his own activities. They are, however, only the activities he wanted known-Arslan remained circumspect about his personal life, his financial arrangements, and his controversial Axis associations.

This gap is partially filled by archival sources. Arslan's activities in Europe and his perceived manipulation of Middle Eastern politics attracted the attention of various European governments, whose files contain revealing comments on his career. They must, however, be used with caution. Not all of them are based on first-hand information, and they occasionally exaggerate his influence and his physical abilities. Their sensationalism says as much about European concerns as it does about Arslan's aspirations. In this context, one exceptional collection of materials should be mentioned. For most of the interwar period, Arslan's base of operations was in Switzerland. His various entanglements discomfited the Swiss authorities, and they elected to keep a close watch on him. He was placed under efficient surveillance, called in for occasional interrogations, and reported on with general accuracy. I regard the prudent Swiss files as dependable sources of information on Arslan's European activities and have used them to resolve some of the controversies surrounding his personal affairs.

In addition to his array of published works, Arslan kept up a prodigious correspondence. The original collection is not in the public domain, ${ }^{1}$ but his letters were intercepted with such frequency by various British, French, Swiss, and Italian agencies as to make a small volume in themselves. His communications with official and semiofficial members of the German diplomatic service are contained in the documents captured by the Allies. Letters from Rashid Rida to Arslan are included in Arslan's biography of Rida, and fiftyfive of Arslan's letters to Rida, covering the years 1922 to I935, are reproduced in Ahmad al-Sharabasi's Amir al-bayan.

The contributions of a figure of such prominence have not gone unrecorded. Two Arab biographers, Ahmad al-Sharabasi of Egypt and 
Sami al-Dahhan of Syria, have created a small publishing industry based on Arslan. ${ }^{2}$ In some cases, my interpretations are identical with theirs; often we differ. In exercising the selectivity imposed on all biographers, they have chosen to gloss over the most controversial aspects of the Amir's career-his relations with Jamal Pasha during World War I and his ties to Italy and Germany during the late I930s. I have seen these controversies as crucial to the development of his reputation and have tried to ascertain their significance. While I have no less respect for Arslan than they do, my assessment of his place in Islamic reformism accords him less originality than does theirs. They have emphasized his commitment to political Arabism while I have downplayed it. They have quite rightly explored his contribution to modern Arabic literature, a subject I have not treated at all. Finally, both of them, in their concern to emphasize Arslan's role in the Eastern Arab world, slight his activities in North Africa. Despite our occasionally divergent emphases, the scholarly debt is mine, and I gratefully acknowledge it.

Some of the sources cited frequently in this study employ the Gregorian and Hijrah years intermittently. For example, in I930/3 I the journal al-Fath discontinued its practice of listing the Gregorian date and began using the Hijrah year exclusively. Similarly, Arslan's published correspondence sometimes uses the Gregorian year, sometimes the Hijrah one. Rather than convert each Hijrah reference, I have cited the dates as they appear in the original source. The table which follows permits a general conversion from the Muslim to the Christian year for the period relevant to the citations in this book. ${ }^{3}$

$\begin{array}{ll}\text { I344 } & \text { 22 July I925 to I Iuly I926 } \\ \text { I345 } & \text { I2 July I926 to 30 June I927 } \\ \text { I346 } & \text { I July I927 to I9 July I928 } \\ \text { I347 } & \text { 20 July I928 to 8 July I929 } \\ \text { I348 } & \text { 9 July I929 to 28 May I930 } \\ \text { I349 } & \text { 29 May I930 to I8 May I93 I } \\ \text { I350 } & \text { I9 May I93 I to 6 May I932 } \\ \text { I35 I } & \text { 7 May I932 to 25 April I933 } \\ \text { I352 } & \text { 26 April I933 to I5 April I934 } \\ \text { I353 } & \text { I6 April I934 to 4 April I935 } \\ \text { I354 } & 5 \text { April I935 to 23 March I936 }\end{array}$


$X$ A NOTE ON SOURCES

I355 24 March I936 to I 3 March I937

I356 I4 March I937 to 2 March I938

I 3573 March I938 to 20 February I 939

I 358 2 I February I939 to 9 February I 940 